\title{
36. ORGANIC GEOCHEMISTRY OF TERRIGENOUS MUDS AND VARIOUS SHALES FROM THE BLACK SEA, DSDP LEG 42B ${ }^{1}$
}

\author{
Bernd R.T. Simoneit, Institute of Geophysics and Planetary Physics, \\ University of California, Los Angeles, California
}

\begin{abstract}
The Black Sea is a sink for terrigenous detritus with rapid sediment accumulation, estimated at $16 \mathrm{~km}$ thickness in the central basin. Lipid markers of terrigenous origin have been identified in most sediment samples that were examined from Sites 379-381. The molecular indicators of terrigenous lipids were $n$-alkanes $\left(n-\mathrm{C}_{25}\right.$ to $n$ $\mathrm{C}_{33}$, odd-to-even predominance, maximum mainly at $n$ - $\left.\mathrm{C}_{29}\right), n$-fatty acids $\left(n-\mathrm{C}_{22}\right.$ to $n-\mathrm{C}_{30}$, even-to-odd predominance, maximum at $n-\mathrm{C}_{24}$ or $\left.n-C_{26}\right)$ and dehydroabietic acid. Steroidal and triterpenoidal compounds were also identified and they probably originated from primary marine or lacustrine production. Perylene was present in most of the samples and is probably associated with terrigenous lipids. The $\delta^{13} \mathrm{C}$ values for the total lipid fractions were in the range typical of a higher plant and/or lacustrine origin.
\end{abstract}

\section{INTRODUCTION}

Lipid markers of terrigenous origin have been identified in Recent sediments recovered by the $R / V$ Atlantis II from the Black Sea (Simoneit, 1974, 1975, in press a). These data, coupled with carbon isotope analyses of lipid fractions, indicated that a major proportion of the lipids were of continental origin. Thus, it is of interest to examine the lipids of the DSDP sediments from the Black Sea in order to assess the input of terrigenous lipids to the older environments. The lithology and palynology reported for the sediment sequences from the three drill sites indicate that terrigenous input occurred during most of the sedimentary history (Ross et al., 1975).

The samples analyzed here were derived from Site 379 , located in the central part of the basin $\left(43^{\circ} 0.3^{\prime} \mathrm{N}\right.$, $36^{\circ} 0.7^{\prime} \mathrm{E}$; water depth $2171 \mathrm{~m}$ ), Site 380 , located at the edge of the basin near the Bosporus $\left(42^{\circ} 5.9^{\prime} \mathrm{N}\right.$, $29^{\circ} 36.8^{\prime} \mathrm{E}$; water depth $2115 \mathrm{~m}$ ), and Site 381 , located upslope of Site 380 near the Bosporus $\left(41^{\circ} 40.3^{\prime} \mathrm{N}\right.$, $29^{\circ} 25^{\prime} \mathrm{E}$; water depth $1750.5 \mathrm{~m}$ ) (Ross et al., 1975).

\section{EXPERIMENTAL}

The core samples were freeze-dried and then extracted with toluene and methanol (4:1) using ultrasonication. The extracts for each sample were concentrated on a rotary evaporator and subjected to gas chromatographic analysis (GC). The extracts were then treated with diazomethane in ether and subjected to silica gel thin-layer chromatography (TLC) using methylene chloride as eluent. The bands corresponding to hydrocarbons, esters, and ketones were scraped off the TLC plate after development with iodine vapor,

\footnotetext{
'Contribution No. 1622, Institute of Geophysics and Planetary Physics, University of California, Los Angeles, California.
}

and eluted with ether or ethyl acetate. These fractions were subjected to GC and GC/MS analyses.

The GC analyses were carried out on a HewlettPackard Model 5830 gas chromatograph using a $16 \mathrm{~m}$ $\times 0.75 \mathrm{~mm}$ stainless steel SCOT column coated with OV-101, programmed from $110-280^{\circ} \mathrm{C}$ at $4^{\circ} \mathrm{C}$ per minute using He carrier gas at a flow rate of $3 \mathrm{ml} / \mathrm{min}$.

The GC/MS analyses were carried out on a DuPont Model 21-492-1 mass spectrometer interfaced directly with a Varian Aerograph Model 204 gas chromatograph equipped with a $10 \mathrm{~m} \times 0.75 \mathrm{~mm}$ glass column which was packed with Gaschrom Q (80-100 mesh) coated with $1 \% \mathrm{OV}-1$. The mass spectrometric data were acquired and processed using a DuPont Model 21094 data system.

The stable isotope analyses were carried out by the methodology described (Kaplan et al., 1970), using Chicago PDB as reference standard.

\section{RESULTS AND DISCUSSION}

The sample descriptions, carbon analyses, lipid yields, and other results are found in Table 1.

The samples from the basin (Hole 379A) are of Pleistocene age and consist of terrigenous and microfossiliferous mud with about $12 \%$ carbonate. The organic carbon content and lipid yields are low. The distribution diagrams for the $n$-alkanes and $n$-fatty acids are shown in Figures 1 and 2, respectively. For Sections 379A-25-4 and 379A-30-3 the $n$-alkanes exhibit a hump with a peak at $n-C_{22}$ (no predominance) and a second homolog distribution with a strong oddto-even carbon number predominance ranging from $n$ $\mathrm{C}_{25}$ to $n-\mathrm{C}_{33}$ (maximum at $n$ - $\mathrm{C}_{29}$ for Sections 379A-24-5 and at $n-\mathrm{C}_{27}$ for 379A-30-3). These second maxima are usually associated with higher plant waxes (Simoneit, 1975 , in press). The first maximum, coupled with the low concentration of $n$ - $\mathrm{C}_{17}$, is typical of microbially altered algal residues. The $n$-fatty acids exhibits a 
TABLE 1

Sample Descriptions, Carbon Analyses, Extract Yields, and Carbon Isotope Values for the Core Sections Examined

\begin{tabular}{|c|c|c|c|c|c|c|c|c|c|c|c|c|c|c|c|}
\hline \multirow{2}{*}{$\begin{array}{c}\text { Sample } \\
\text { (Interval in cm) }\end{array}$} & \multirow{2}{*}{$\begin{array}{c}\text { Depth } \\
\text { Below } \\
\text { Seabed } \\
\text { (m) }\end{array}$} & \multirow[b]{2}{*}{ Lithology } & \multirow{2}{*}{$\begin{array}{c}\text { Geologic } \\
\text { Age }\end{array}$} & \multirow{2}{*}{$\begin{array}{c}\text { Total } \\
(\%)\end{array}$} & \multicolumn{2}{|c|}{ Carbon $^{a}$} & \multirow{2}{*}{$\begin{array}{c}\mathrm{Pr} / \mathrm{Ph} \\
\text { (hydrocarbon) }\end{array}$} & \multirow{2}{*}{$\begin{array}{l}\text { Perylene } \\
\text { Presence }\end{array}$} & \multirow{2}{*}{$\begin{array}{l}{ }^{813} \mathrm{C}^{b} \\
(1 / 00)\end{array}$} & \multicolumn{2}{|c|}{$\begin{array}{c}n- \\
\text { alkanes }\end{array}$} & \multicolumn{2}{|c|}{$\begin{array}{l}\text { Lipid Yields } \\
n \text {-fatty } \\
\text { acids }\end{array}$} & \multicolumn{2}{|c|}{$\begin{array}{c}n- \\
\text { ketones }\end{array}$} \\
\hline & & & & & $(\%)$ & $(\%)$ & & & & $\mu \mathrm{g} / \mathrm{g}$ & CPI & $\mu \mathrm{g} / \mathrm{g}$ & CPI & $\mu \mathrm{g} / \mathrm{g}$ & CPI \\
\hline $\begin{array}{l}379 \mathrm{~A}-25-4, \\
0-5\end{array}$ & 230.0 & Terrigenous & Pleistocene & 2.1 & 0.6 & 13 & 0.8 & H+ & -29.8 & 80 & 1.6 & 50 & 5.3 & n.d. & - \\
\hline $\begin{array}{l}379 \mathrm{~A}-30-3 \\
100-105\end{array}$ & 277.0 & $\begin{array}{l}\text { Nanno, } \\
\text { Diatom. mud }\end{array}$ & Pleistocene & 1.9 & 0.4 & 12 & - & + & n.d. & 6 & 1.2 & 10 & 12.7 & 10 & 4.7 \\
\hline $\begin{array}{l}380 \mathrm{~A}-3-1 \\
78-91\end{array}$ & 352.4 & $\begin{array}{l}\text { Diatom. mud, } \\
\text { dolom. marl }\end{array}$ & Pleistocene & 2.4 & 0.5 & 16 & n.d. ${ }^{\mathrm{c}}$ & n.d. & n.d. & n.d. & - & n.d. & - & n.d. & - \\
\hline $\begin{array}{l}380 \mathrm{~A}-21-3 \\
66-72\end{array}$ & 526.2 & $\begin{array}{l}\text { Calcareous } \\
\text { ooze and mud }\end{array}$ & Pleistocene & 1.5 & 0.4 & 10 & - & + & -29.5 & 10 & 2.9 & 3 & 5.3 & 1.0 & 2.9 \\
\hline $\begin{array}{l}380 \mathrm{~A}-74-1 \\
106-112\end{array}$ & 1017.5 & $\begin{array}{l}\text { Diatom } \\
\text { shale }\end{array}$ & Pleistocene & 2.3 & 0.9 & 12 & 0.2 & + & -27.9 & 40 & 2.5 & 8 & 3.2 & 7 & 1.2 \\
\hline $\begin{array}{l}380 \mathrm{~A}-78-6, \\
22-26\end{array}$ & 1062.2 & Black shale & L. Pliocene & 2.6 & 1.1 & 13 & 1.4 & + & -24.9 & 75 & 1.2 & 13 & 2.4 & n.d. & - \\
\hline $\begin{array}{l}381-1-4 \\
104-115\end{array}$ & 5.5 & $\begin{array}{l}\text { Terrigenous } \\
\text { mud }\end{array}$ & Pleistocene & 3.8 & 2.0 & 15 & 0.8 & + & -27.5 & 120 & 2.7 & 200 & 15.1 & 100 & 4.4 \\
\hline $\begin{array}{c}381-2-3 \\
67-73\end{array}$ & 13.2 & $\begin{array}{l}\text { Terrigenous } \\
\text { mud }\end{array}$ & Pleistocene & 1.0 & 0.5 & 4 & n.d. & n.d. & n.d. & n.d. & - & n.d. & - & n.d. & - \\
\hline $\begin{array}{c}381-6 \cdot 1 \\
19-30\end{array}$ & 47.7 & $\begin{array}{l}\text { Terrigenous } \\
\text { mud }\end{array}$ & Pleistocene & 1.5 & 0.3 & 10 & n.d. & n.d. & n.d. & n.d. & - & n.d. & - & n.d. & - \\
\hline $\begin{array}{c}381-37-3 \\
32-42\end{array}$ & 335.9 & $\begin{array}{l}\text { Diatom. } \\
\text { sapropelic mud }\end{array}$ & Pleistocene & 6.8 & 5.1 & 15 & 0.9 & - & -27.2 & 30 & 4.2 & 10 & 4.3 & n.d. & - \\
\hline $\begin{array}{c}381-54-5 \\
94-101\end{array}$ & 500.9 & $\begin{array}{l}\text { Shale } \\
\text { breccia and } \\
\text { siltstone }\end{array}$ & U. Miocene & 1.6 & 1.4 & 2 & - & +++ & -27.9 & 2 & 3.5 & 1.6 & 4.0 & n.d. & - \\
\hline
\end{tabular}

a Data supplied by G. Bode and S. M. White, Deep Sea Drilling Project, Scripps Institution of Oceanography, University of California at San Diego.

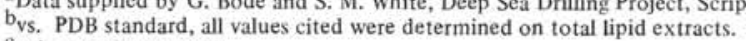

$c_{\text {n.d. - not determined. }}$
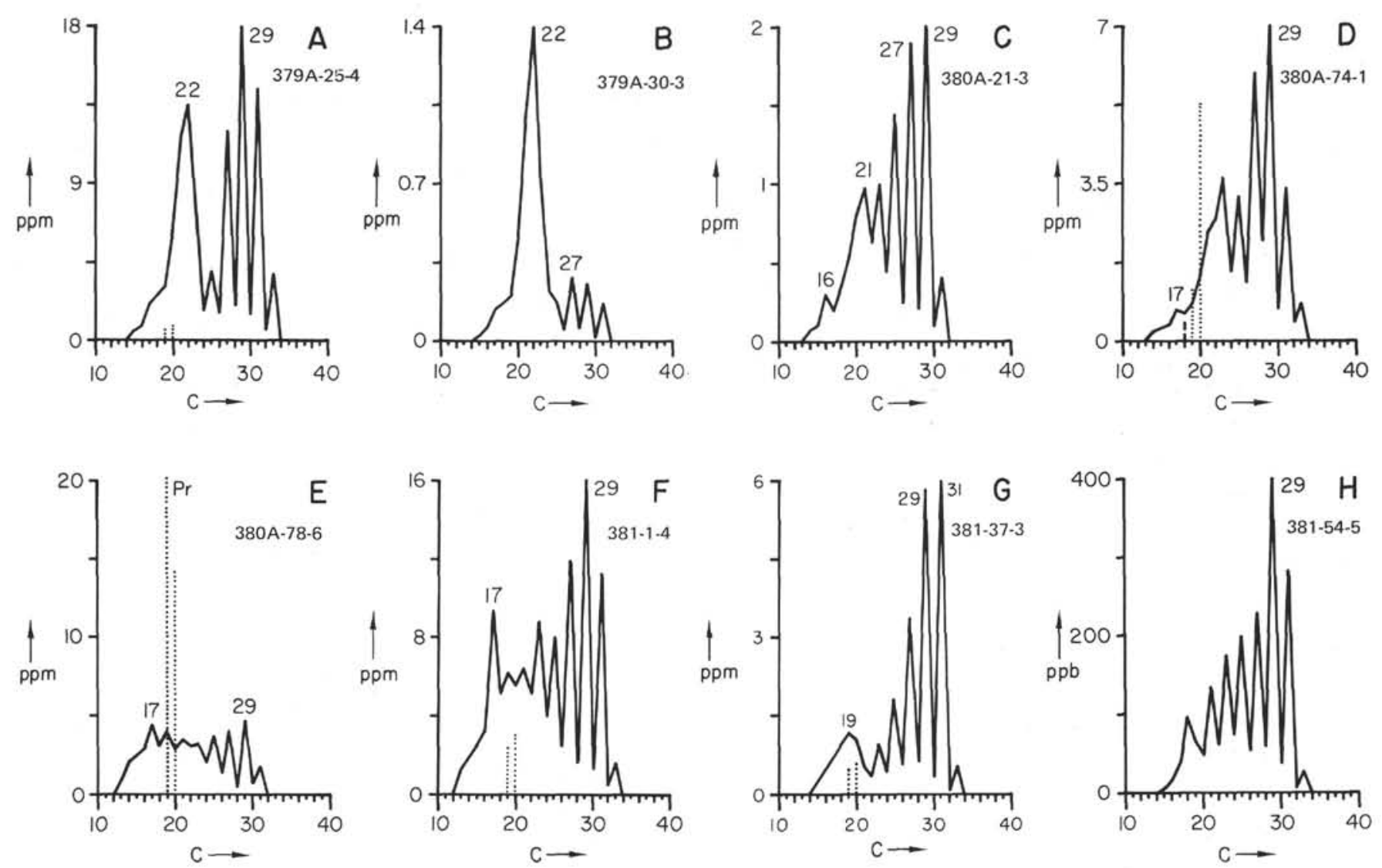

Figure 1. Distribution diagrams for the $n$-alkanes $(\cdots$ isoprenoids, $\cdots$ diterpenoid)

bimodal distribution with a strong even-to-odd carbon number predominance and modal maxima at $n-\mathrm{C}_{16}$ and at $n-\mathrm{C}_{26}$ for Section $379 \mathrm{~A}-25-4$ and $n-\mathrm{C}_{24}$ for Section 379A-30-3 (minor amount only). The maximum at $n$ $\mathrm{C}_{16}$ (i.e., $<n-\mathrm{C}_{20}$ ) appears to be of autochthonous marine and/or lacustrine origin. The distributions $>n$ $\mathrm{C}_{22}$, when considered in conjunction with the $n$-alkane distributions, are further evidence for higher plant wax inputs (Hitchcock and Nichols, 1971; Simoneit, 1975). The low amount of higher weight fatty acids in the case 

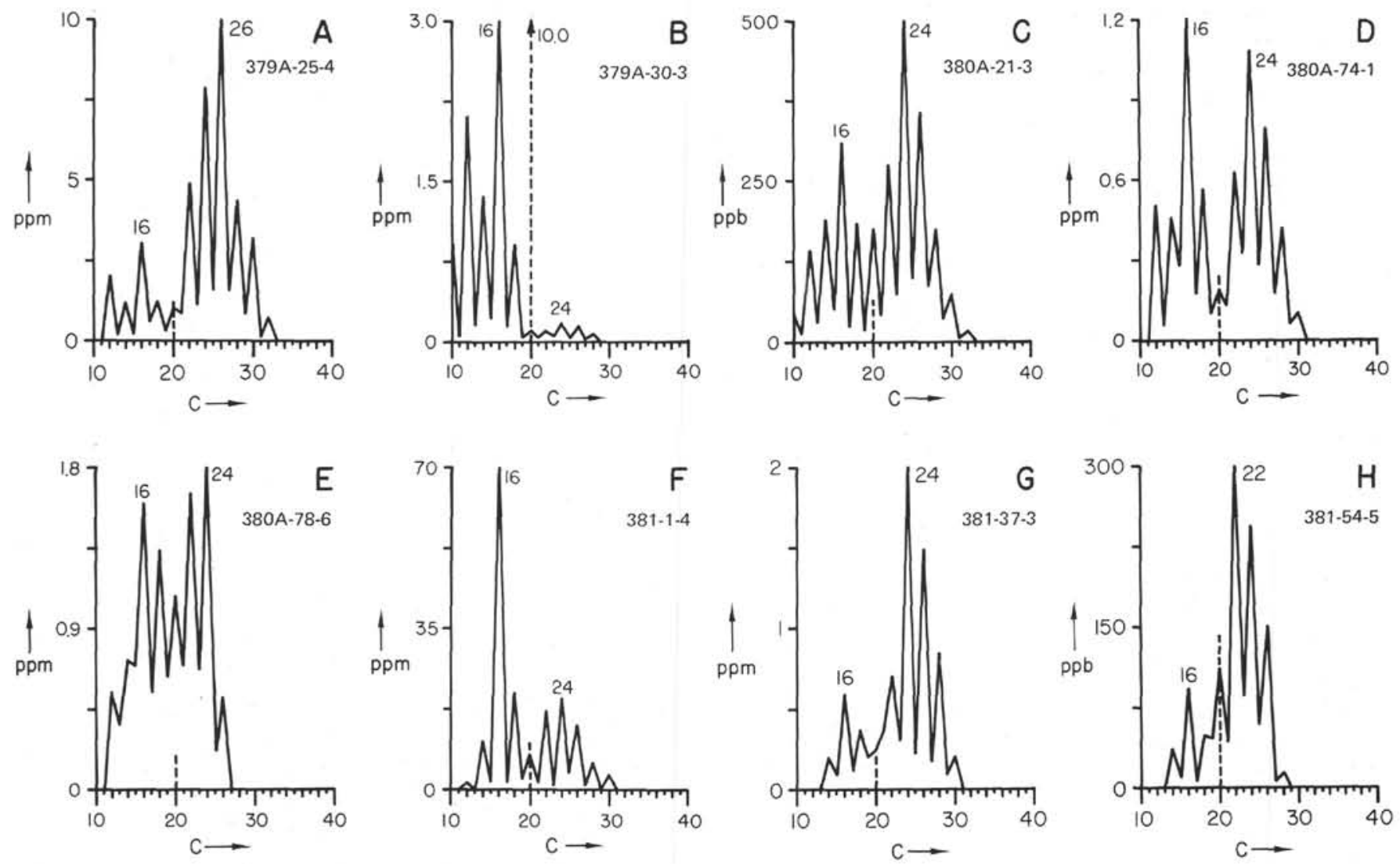

Figure 2. Distribution diagrams for the $n$-fatty acids (-.-diterpenoid)

of Section 379A-30-3 may be due to removal by microbial activity. The diterpenoid, dehydroabietic acid (Appendix, Structure I) is present in both samples. This compound is a marker of terrigenous resinous plants (Simoneit, 1977). The ketone fraction of Section 379A-30-3 consists predominantly of normal methylketones, $\mathrm{C}_{n} \mathrm{H}_{2 \mathrm{n}} \mathrm{O}$, ranging from $\mathrm{n}=14$ to 31 , with a strong odd-to-even carbon number predominance and a maximum at $n-\mathrm{C}_{27}$ (Figure 3a). 6, 10, 14-Trimethylpentadecan-2-one (Structure II) is also present in this fraction. The normal ketones are probably derived from $n$-fatty acids by microbial $\beta$-oxidation or by microbial oxidation of $n$-alkanes (Arpino, 1973). Thus, this distribution pattern also reflects a terrigenous origin. Perylene (Table 1) is present in both samples.

The samples from the western Black Sea (Hole 380A and Site 381) range in age from Pleistocene to late Miocene and they are predominantly of terrigenous lithology with $2 \%-15 \%$ carbonate (Table 1). The organic carbon contents range from $0.3 \%$ to $5 \%$, but the lipid yields are relatively low.

The $n$-alkanes of all samples (380A-21-3, 380A-74-1, $381-1-4,381-37-3$, and 381-54-5) exhibit a distribution where the homologs from $n-C_{23}$ to $n-C_{33}$ predominate (maxima at $n-\mathrm{C}_{29}$ or $n-\mathrm{C}_{31}$ ) and a minor maximum is observed in the range from $n-\mathrm{C}_{17}$ to $n-\mathrm{C}_{21}$ (Figure 1). These higher weight $n$-alkanes are derived from plant wax sources (Simoneit, 1975, in press) and are dominant over autochthonous components $\left(<n-\mathrm{C}_{22}\right)$ in the paleoenvironments closer to shore. The $n$-fatty acids of the samples from Hole $380 \mathrm{~A}$ and Site 381 exhibit a bimodal distribution with strong even-to-odd carbon number predominances and maxima at $n-\mathrm{C}_{16}$ and $n-\mathrm{C}_{24}$ and $n-\mathrm{C}_{22}$ (Section 381-54-5) (Figure 2). The maximum at $n-\mathrm{C}_{16}$ is derived from autochthonous lacustrine and/or marine production. The distributions $>n$ - $\mathrm{C}_{20}$, when considered with the $n$-alkanes $>n-\mathrm{C}_{23}$, are further indications of higher plant lipid input. Dehydroabietic acid (Structure I) is present in all samples and is an indicator of input from resinous plants (Simoneit, 1977). The ketone fractions (Sections 380A-21-3, 380A-74-1, and 381-1-4) consist of normal methyl and isoprenoidal ketones (Figure 3) and triterpenoidal ketones. The normal series, $\mathrm{C}_{\mathrm{n}} \mathrm{H}_{2 \mathrm{n}} \mathrm{O}$, range from $\mathrm{n}=11$ to 33 , with odd-to-even carbon number predominances and bimodal distributions. These ketones are microbial alteration products (Arpino, 1973), and thus the distributions $>n-C_{21}$ reflect a terrigenous origin. The isoprenoidal ketones consist of predominantly 6,10,14-trimethylpentadecan-2-one (Structure II) and in Sections 380A-74-1 and 381-1-4 lesser amounts of 6,10-dimethylundecan-2one (Structure III).

The alicyclic compounds found in this sample suite consist principally of steroidal and triterpenoidal compounds. The shallower samples contain predominantly sterenes, $\mathrm{C}_{\mathrm{n}} \mathrm{H}_{2 \mathrm{n}-8}$ for $\mathrm{n}=27$ to 29 (Structure IV, $\mathrm{R}=\mathrm{H}$ ) and minor amounts of stanones, $\mathrm{C}_{\mathrm{n}} \mathrm{H}_{2 \mathrm{n}-8} \mathrm{O}$ for $\mathrm{n}=27$ to 29 . The deeper samples (e.g., 381-54-5 and 380A-74-1) contain primarily steranes, $\mathrm{C}_{\mathrm{n}} \mathrm{H}_{2 \mathrm{n}-6}$ for $\mathrm{n}=27-29$ (Structure V), with the $5 \alpha$ stereochemistry. Section 380A-74-1 also contains minor 

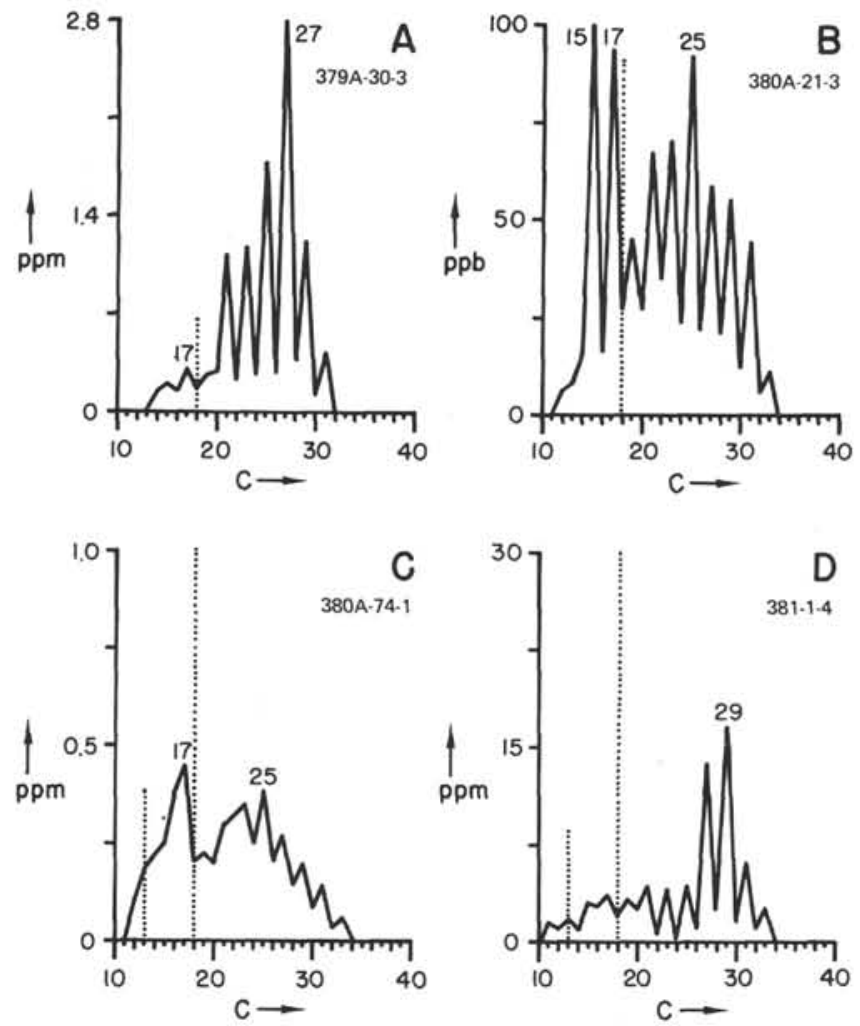

Figure 3. Distribution diagrams for the n-ketones $(. .$. isoprenoids)

amounts of 4-methylsterenes (Structure IV, $\mathrm{R}=\mathrm{CH}_{3}$ ), $\mathrm{C}_{\mathrm{n}} \mathrm{H}_{2 \mathrm{n}-8}$ for $\mathrm{n}=28$ and 29 ; the double bond position is uncertain. The ketone fractions from Sections 381-1-4 and 380A-74-1 contain significant amounts of probably 4-methylstan-3-ones, $\mathrm{C}_{n} \mathrm{H}_{2 \mathrm{n}-8} \mathrm{O}$ for $\mathrm{n}=28$ to 30 . The triterpenoids consist mainly of the hopane and moretane skeleton. In the shallower samples the predominant species are diploptene (Structure VI), adiantanes (Structure VII) and hopane or moretane (Structure VIII). Standard compounds were not coinjected, therefore the stereochemistry of the $\mathrm{C}_{30} \mathrm{H}_{52}$ species cannot be assigned. In the deeper samples (e.g., 380A-74-1) the major triterpenoids are comprised of adiantanes (Structure VII), hopane or moretane (Structure VIII), the predominant species $17 \beta(\mathrm{H})$ homohopane (Structure IX), and a minor amount of its stereoisomer $17 \alpha(\mathrm{H})$-homohopane (Structure $\mathrm{X}$ ). Section 380A-74-1 also contains about $10 \mathrm{ppm}$ of triterpenoidal acids. The major species is $17 \beta(\mathrm{H})$ bishomohopanoic acid (Structure XI, $\mathrm{R}=\mathrm{CH}_{2} \mathrm{COOH}$ ) and the minor homologs are $\mathrm{C}_{\mathrm{n}} \mathrm{H}_{2 \mathrm{n}-10} \mathrm{O}_{2}$, with $\mathrm{n}=31$ [both $17 \alpha$ and $\beta(\mathrm{H})$, Structures XI and XII], $\mathrm{n}=32$ $[17 \beta(\mathrm{H})$, Structure $\mathrm{XII}]$, and $n=33[17 \beta(\mathrm{H})$, Structure XI]. The triterpenoidal ketones are composed of mainly trisnorhopan-21-one (Structure XIII), adiantones (Structure XIV) and a $\mathrm{C}_{30}$ ketone (probable Structure XV).

Retene (Structure XVI), a diterpenoidal dehydrogenation product (Simoneit, 1977), is present in Sections 381-37-3 and 380A-74-1. Most samples contain perylene $\left(\mathrm{C}_{20} \mathrm{H}_{12}\right)$ (Table 1$)$, which elutes on TLC as a bright yellow band just below the hydro- carbons. An example of a UV-visible spectrum of this component is shown in Figure 4 which corresponds well with that of the standard compound (Simoneit, 1975). Perylene may be a terrigenous marker (Aizenshtat, 1973) since it has been mainly encountered in sediments with lipids of predominantly such an origin (Simoneit, 1975). The perylene of these samples appears to be of a terrigenous origin.

The analyses of the stable carbon isotopes support a terrigenous and/or lacustrine origin for the total lipids. The $\delta^{13} \mathrm{C}$ values observed for the lipids range from -24.9 to $-29.8 \%$ (Table 1). These values fall within the ranges typical of terrestrial plants, some lacustrine higher plants and fresh water plankton (Degens, 1969). They are, however, outside the typical range of values observed for marine organic matter, which is within $\delta^{13} \mathrm{C}=-12$ to $-23^{\circ} \%$ (Degens, 1969).

Contamination from various plasticizers and lubricants is minor and consists predominantly of dibutyl, dioctyl, and heptyl nonyl phthalates.

\section{CONCLUSIONS}

The lipid extracts from Pleistocene to upper Miocene samples from the Black Sea (Sites 379A, 380A, and 381) have $n$-alkanes, $n$-fatty acid, and $n$-methylketone distributions typical for a terrigenous and/or lacustrine origin. Potamic transport appears to have brought in the allochthonous component of the lipids. The lipids of samples from Hole 380A and Site 381 reflect predominantly higher plant wax distributions and dehydroabietic acid, the molecular marker of resinous plants, is also present. The samples from the basin (Hole 379A) have a lipid content reflecting a microbial component of lacustrine and/or marine origin and a

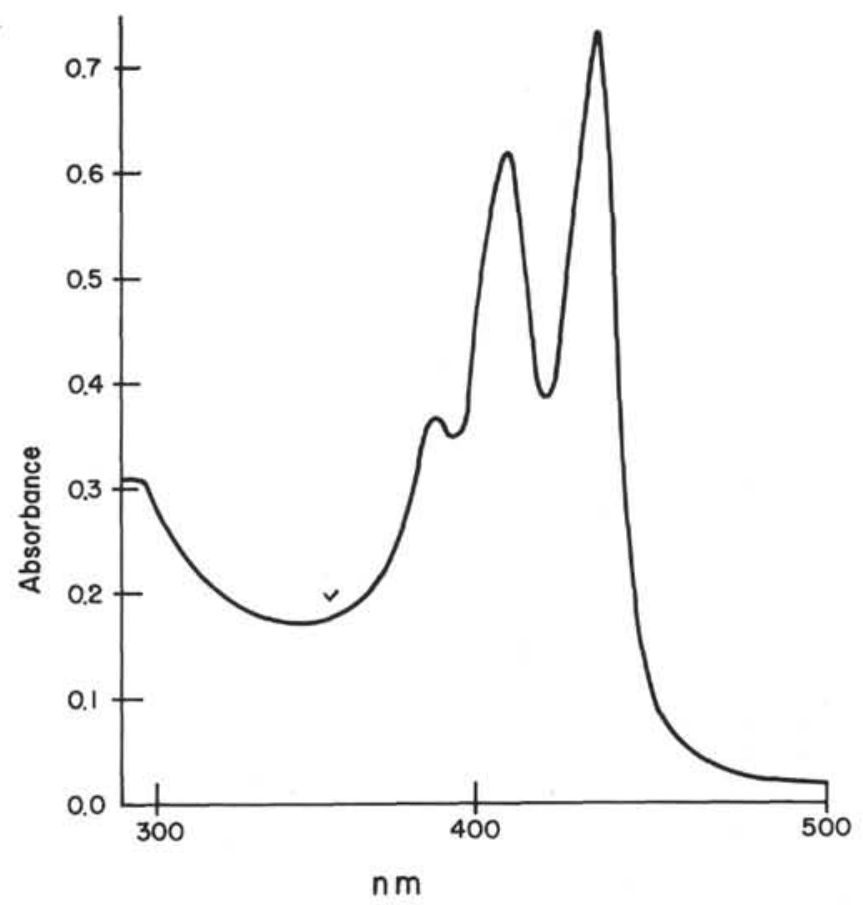

Figure 4. UV-Visible spectrum of perylene from Section 381-54-5 /Cary Model 15 spectrophotometer, pathlength $1 \mathrm{~cm}$, in $\mathrm{CH}_{2} \mathrm{Cl}_{2}$ ). 
higher plant wax component. Dehydroabietic acid is also present in these samples. The $\delta^{13} \mathrm{C}$ values for the total lipids are in the range typical of a higher plant and/or lacustrine origin. The steroidal and triterpenoidal compounds in the lipids probably originate from primary autochthonous production. The perylene appears to be associated with terrigenous lipids. Based on these data it can be concluded that the paleoenvironment of the Black Sea (at these sampling points) was lacustrine, with a high potamic influx of terrigenous higher plant lipids. Some of the $\mathrm{Pr} / \mathrm{Ph}$ values (Table 1 ) are $<1$, which may indicate anoxic paleoenvironmental conditions (Didyk et al., in press).

\section{ACKNOWLEDGMENTS}

I thank the National Science Foundation for making the core samples available, R.P. Philp and S.C. Brown for GC/MS data, D. Winter for stable isotope analyses, and I. Venkatesan for technical assistance. Partial financial assistance from the National Science Foundation (Grant Nos. OCE 76-21506 and OCE 76-23390) and the Energy Research and Development Administration (Grant No. [E (04-3)-34 p.a. 134]) is gratefully acknowledged. I thank Drs. D.A. Ross and J.R. Herring for the review of the manuscript.

\section{REFERENCES}

Aizenshtat, Z., 1973. Perylene and its geochemical significance: Geochim. Cosmochim. Acta, v. 37, p. 559567.

Arpino, P., 1973. Les lipides des sédiments lacustres éocènes: Thèse, l'Université Louis Pasteur de Strasbourg, France.

Degens, E.T., 1969. Biogeochemistry of stable carbon isotopes. In Eglinton, G and Murphy, M.T.J. (Eds.), Organic geochemistry, methods and results: Berlin (Springer-Verlag), p. 304-329.

Didyk, B.M., Simoneit, B.R.T., and Eglinton, G., in press. Geochemical indicators of paleoenvironmental conditions of sedimentation: Nature.

Hitchcock, C. and Nichols, B.W., 1971. Plant lipid biochemistry: London (Academic Press).

Kaplan, I.R., Smith, J.W., and Ruth, E., 1970. Carbon and sulfur concentration and isotopic composition in Apollo 11 lunar samples. In Apollo 11 Lun. Sci. Conf. Proc.-Geochim. Cosmochim. Acta, Suppl. 1, v. 2: New York (Pergamon), p. 1317-1329.

Ross, D.A., Neprochnov, Y., Hsü, K., Senalp, M., Stoffers, P., Supko, P., Trimonis, E.A., Percival, S., Traverse, A.,
Erickson, A.J., Degens, E.T., Hunt, J.M., and Manheim, F., 1975. Glomar Challenger drills the Black Sea: Geotimes, v. 20, p. 18-20.

Simoneit, B.R.T., 1974. Organic analyses of Black Sea cores. In Degens, E.T. and Ross, D.A. (Eds.), The Black Sea-geology, chemistry and biology: Am. Assoc. Petrol. Geol., Mem. 20, p. 477-498.

, 1975. Sources of organic matter in oceanic sediments: Ph.D. Thesis, University of Bristol, England. 1977. Diterpenoid compounds and other lipids in deep-sea sediments and their geochemical significance: Geochim. Cosmochim. Acta, v. 41, p. 463-476. in press. The Black Sea, a sink for terrigenous lipids: Deep-Sea Res.
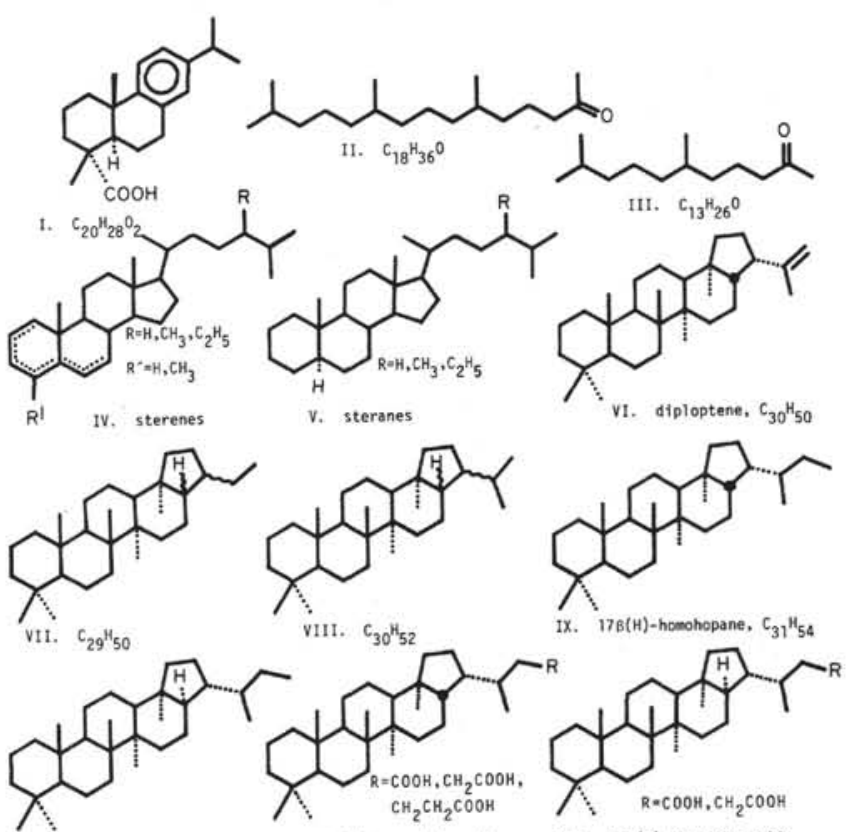

x. $17 \alpha(\mathrm{H})$-hooohopane, $\mathrm{C}_{31} \mathrm{H}_{54}$ XI. $17 \mathrm{~B}(\mathrm{H})$-hopanoic acids XI1. 17a(H)-hopanoic acids

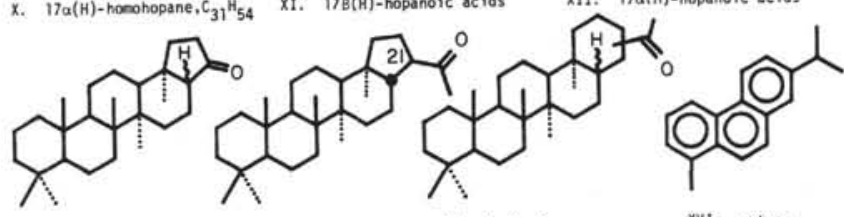

X111. trisnorhopan-21-one XIV. adiantones XV. $\mathrm{C}_{30} \mathrm{H}_{50}{ }^{\circ} \quad$ XVI. retene 